\title{
Idiomatic Expression Used in Malay Labuhanbatu Wedding Ceremony
}

\author{
$\underline{\text { Sisila Fitriany Damanik }}{ }^{1}$, Tiarnita Maria Sarjani Siregar ${ }^{2}$ \\ ${ }^{1,2}$ English Department, Faculty of Languages and Arts, Universitas Negeri Medan, Indonesia \\ Email: SFDamanik@gmail.com
}

\begin{abstract}
The aim of this study is to find out types of idiomatic expression in Malay Labuhanbatu Wedding Ceremony (MLWC). This study was conducted by applying descriptive qualitative research. The data were collected by applying documentary and interview technique, and applying the theory of Charles F Hockett to analyzed the types of idiomatic expression in MLWC. Charles $F$ Hockett divides the types of idiomatic expression into 5 types, Proper Names, Abbreviation, English Phrasal Compounds, Figure of Speech and the theory of Abdul Chaer is used to analyzed the applying of Idiomatic expression in MLWC. After analyzing the data, it is found that Malay Labuhanbatu wedding ceremony are used to maintain the respect in the social relation of society, to preserve the Idiomatic Expresssion in Malay Labuhanbatu, and to enrich the Malay language, and the last to present the Malay Culture through the use of idiom.

Keywords: idiomatic expression; idiom; pure idiom; figure of speech; proper names
\end{abstract}

\section{Introduction}

In this world every human being needs a language to communicate and it cannot be separated in human's life. According to Gleason and Ratner (1998:2) language is so basic to our existence that life without words is difficult to envision. By these statements we can conclude that human being cannot live without language, without language we cannot interact and communicate each other, and we cannot express our feeling and our idea. When we use the language, we have to know the meaning of words or sentences we utter. Therefore, we need to study about Semantic. Yule (2006:112) defines Semantics is the study of the meaning of words, phrases and sentences. In Yule's semantic analysis, there are phrases or expressions consisting of more than one word or sentence, in which the meaning cannot be translated from the meanings of the individual words. For these expressions, the usual semantic rules for combining meanings cannot be applied. Such expressions are called idioms. Idiom is a phrase or a sentence which meaning cannot be literally translated. Language and culture has the important relation, According to Yule (2006:216) states that use the term culture to refer to all the ideas and assumptions about the nature of things and people that we learn when we become members of social groups. It can be defined as 'socially acquired knowledge'.

This is the kind of knowledge that, like our first language, we initially acquire without conscious awareness. We develop awareness of our knowledge, and hence of our culture, only after having developed language. These statement indicates that cultural development begins with the development of language in life. Kramsch (1998: 3) states that Language is the principal means whereby we conduct our social lives. When it is used contexts of communication, it is bound up with culture in multiple and complex ways. To begin with, the words people utter refer to common experience. They express facts, ideas or events that are communicable because they refer to a stock of knowledge about the world that other people share. Words also reflect their author's attitudes and beliefs, their point of view that are also those of other. In both case, language expresses cultural reality, by both of statements we can conclude that Language and culture cannot be separated and also people need language to communicate the process of the traditional wedding ceremony. 
Indonesia is well known as an archipelago which means that there are a thousand of big or small island. Each of them has its own traditions and customs that becomes a wealth of the nation. Malay is one of the famous ethnic groups in Indonesia, especially in Sumatra, that believes in traditions and customs. In North Sumatera, Malay is divided into some ethnics. It is in line with Arifin's (2009:2) statement that there are so many kinds of Malay such as: Malay Tamiang, Malay Seruwei, Malay Langkat, Malay Deli, Malay Serdang, Malay Asahan, Kualoh, Pane, Kota Pinang, Labuhanbatu, Lingga, Bilah. Malay also has many traditions and one of them is Traditional Wedding Ceremony. Idiomatic expression commonly used in the wedding process. In this study the researcher present the idiomatic expression in the Meminang (Proposing) Process of Malay wedding ceremony as the preliminary data as following:

Luckman (2005: 62) "Kami ada mempunyai seekor kumbang bernama Fabrurozi Kumbang kami sungguh sudah bersayap tetapi baru pandai terbang. Rupanya suatu bari waktu ia belajar terbang kesana kemari, melintaslab ia di rumah bertuah ini. Tiba-tiba terpandangnya olehnya sekuntum bunga dalam taman ini, rupanya pandangan pertama itu sungguh merasuk sukmanya".

The words seekor kumbang doesn't mean the kind of insect, it means seorang laki-laki (a man), and the words of sudah bersayap it means sudah dewasa (being an adult) and the word of terbang means mencari jodoh ( looking for mate) and the clauses of sekuntum bunga dalam taman means seorang gadis di sebuah rumah (a girl in the house).

Traditional wedding ceremony is one of a universal phenomenon exists in Society. A wedding is a ceremony where two people are united in marriage. Wedding traditions vary greatly between cultures, ethnic groups, religions, countries, and social classes. In a marriage there is a cultural structure that personifies a set of rules, views of life, values, or certain underlying principles and lives in the culture of the society concerned Malay Wedding Ceremony implemented by Islamic rules. The implementation of Malay Labuhanbatu Wedding is generally the same as the Malay tribe in North Sumatra. In wedding ceremony the people eventually use a specific style of language which is commonly known as Idiomatic expression. Based on the explanations above it is interested in conducting a research related to what types of idiomatic expression found in MLWC, how the idiomatic expression are realized in MLWC, and why the idiomatic expression are realized in MLWC as they are. Since this study has never been studied previously, it is expected to enrich the knowledge about MLWC. The researcher would also to know how idiomatic expression can contribute in the process of MLWC.

\section{Review of Literature}

To discuss the idiomatic expression, it is spontaneously related with the study of semantics. Some definitions of semantic have been defined by some experts. Yule (2006:112) defines Semantics is the study of the meaning of words, phrases and sentences. Gennaro and Sally (1992:1) defines Semantic is the branch of linguistic devoted to the investigation of linguistic meaning, the interpretation of expression in a language system. Cipollone \& Vasishth (1998:216) defines Semantic as a subfield of linguistics is the study of meaning in language. Semantic deals with the meaning of words, and how the meanings of sentences are derived from them. In addition, Idiomatic Expressions are defined as an expression whose meanings cannot be inferred from the meanings of the words that make it up. On the other hand, it is also defined as an expression, word, or phrase that has a figurative meaning conventionally understood by native speakers. This meaning is different from the literal meaning of the idiom's individual elements. In other words, idioms do not mean exactly what the words say. 
Idiom is a phrase or sentence whose meaning that can't be understood of the individual meanings of the constituent words but must be learned as a whole and idiom must be seen from all aspect of the context. To support those statement Chaedar (1993:165) states that idiom is the group of words whose has own different meaning but the meaning cannot be defined from the words that from word that perform it. Cipollone, Keiser \& Vasishth (1998:227) state that idiom are cases where a sequence of words has a fixed meaning that is not composed of the literal meaning of its words by regular principles. For the example: the sentence He kicked the bucket can be used to mean "he died." We cannot determine this meaning by combining the meaning of kick and the meaning of The Bucket in the normal way, but rather we must learn the special meaning of the whole phrase kick the bucket as if it were a new "word" Similarly, with to pull someone's leg or red herrin, we can't understand the meaning simply by combining pull with leg, or red with herring.

Chaer 2012: 296 states that Idiom is a unit of term whose meaning cannot be "predicted" from the meaning of its elements, either lexically or grammatically. For example, in grammatically the term menjual rumah (selling a house) means the seller receives the money and the buyer receives the house. The term menjual sepeda (selling a bicycle) means the seller receive the money and the buyer got the bicycle, but in Indonesian term of menjual gigi does not mean so, but it means 'laugh loudly', so the meaning of menjual gigi is called idiomatic meaning. The other example of idiomatic meaning is membanting tulang it means 'work hard' meja bijau means 'court' and sudah beratap seng means 'already old'. The example of Idiomatic expression in Malay, tobal muka (tebal muka) means shameless, We cannot determine this meaning by combining the meaning of tobal and the meaning of muka in the normal way, the term bosar mulut means liar or arrogant, the term otak udang means stupid.

According to Takari, Zaidan and Fadlin (2014) generally, the Malay tends to be a rural people. Even in countries such as Sumatera Utara, they are found living together in villages. Most of the Malay is fisherman and farmers. They may also work on small rubber tree plantations. Others work as laborers on large agricultural estates. Certain traditional of Malay arts and crafts still flourish, such as the making of batik cloth and the production of metals.

Malay Labuhanbatu is one of the ethnics in Sumatra that uses idiomatic expression as their habit in communicate something to other, especially in wedding ceremony. Winona (2017) states that the indigenous population in Labuhan Batu is Malay ethnic. This ethnic partially lives on the coastal area in Labuhan Bilik, one of the districts in Labuhan Batu. Labuhan Bilik is a land of Malay which was evidenced historically by the existence of the Kingdom of Bilah and Panai which is a Malay Kingdom in Labuhan Batu. As one of the Regency in North Sumatra, Labuhanbatu is a regency inhabited by various ethnic groups, namely Malay, Mandailing, Java, Batak Toba, Padang, Karo, Dairi, Nias, Aceh, Chinese, and others.

According to Winona (2017) Malay Labuhanbatu Wedding Ceremony held in several stages they are Merisik, Meminang, Antar Belanja, Menggantung, Ijab Qabul, Berinai, Khatam Al-Quran, Berarak, Membuka Pintu, Bersanding, Tepung Tawar, Makan Hadap-hadapan, Menyembah Mertua, Mandi Kumbo Taman.

\section{a. Merisik ( Investigating/Spying)}

When it is time for a young man to get married his family will look around to identify a number of potential candidates. Having decided upon one particular young lady, then, the merisik of investigation process takes place. For this ceremony one or more representatives (wakil) of the young man's family will pay a friendly visit to the family of the young woman whom they have in mind as his potential bride. The visit is purely for the purpose of further investigation. It allows the visitors to see the young lady. 
A hint will be given to her parents regarding the purpose of the visit, and their reaction will be assessed. The girl's parents may also give the visitors some idea as to whether or not their daughter will be interested in the match. The merisik does not constitute a formal proposal. Following the visit both sides can begin to think more seriously about the possibility or otherwise of the union. It is possible that no progress may take place, and the young man's parents or representatives will then look for another possible candidate.

\section{b. Meminang (Proposing)}

After the process Merisik finished and both of the families agreed to married their children, the next stage is Meminang (Proposing), In this process, the bridegroom's family sends the representative to deliver a marriage proposal to potential bride, the representative who sent is a wise one and understand about the Malay Custom The propose are usually delivered in polite language and also with Pantun and begins with Tepak Sirih.

\section{c Antar Belanja ( sending a gift)}

The next stage before waiting for the wedding day, the Potential bride groom doing Antar Belanja, it is sending the certain items, such as Money or a ring the aim is to help the needs in preparing the wedding ceremony.

\section{d. Menggantung (decorating the house)}

Menggantung is the activity of decorating the house, the bridal dais and also the bed that is in the bride's house, the decorating is done by family and also neighbors, at this stage Tepung Tawar ritual is performed in each the corner places.

\section{e. Ijab Kabul (solemnization)}

The Ijab Kabul is the actual religious solemnization of the marriage. While all the other ceremonies performed in a Malay wedding before the Ijab Kabul and after it may be considered as derived from the traditional culture of the Malays, and may even be omitted the Ijab Kabul is an Islamic ceremony without which no marriage is valid. Consent of both the bride and the bridegroom must be obtained, and the religious official (usually a kadhi) conducting the marriage must make sure the marriage is entered into willingly by both the parties. At times the marriage solemnization is in fact done by the girl's father in the presence of religious officials. In a brief sermon given by the officials, the bridegroom and the bride will receive a briefing on their rights and responsibilities as a married couple, particularly from the Islamic perspective. There must be two official witnesses at the Ijab Kabul. A marriage certificate will be issued by the kadhi or State Religious Council representatives following the ceremony, and this is to be signed by the bridegroom, the bride as well as the witnesses.

\section{f. Malam Berinai ( henna painting ceremony)}

Malam Berinai is the giving henna ceremony to the bride and groom before the wedding party the next day. Henna made by henna leaf pounded with rice and tamarind, The Adat Berinai is intended to cleanse both the young persons now married to each other. Henna is regarded as a blessed item, that is, it is used as a means of cleansing and protection from evil or malicious influences.

\section{g. Khatam Kaji ( completion of Qur'an reciting )}

Khatam kaji is the process of read the holy Quran start from Surah Ad-Dhuha until Annas, hatam kaji usually held in the morning until noon that accompanied by marhaban tradition (Islamic caroling) contains chanting of $\mathrm{Al}$ qur'an holy verses and nasyid poetry, Marhaban played by Women Marhaban Group. 


\section{h. Berarak (Parade)}

The ceremony of Berarak is the activity that the bridegroom walks slowly toward bride's house, usually the groom will be accompanied by his uncle as hope that they come from a respectable family. Behind them come the group of musicians beating various types of drums, The arriving party take their seats in a special area of the house for the martial arts (pencak silat) performance which is held as a sign of welcome and paying respects to the bridegroom as the king for the day.

\section{i. Membuka Pintu (gateway barrier)}

Membuka pintu the stage which two men standing on the left and right of the door and they hold long cloth that was stretched. The purpose is that the bride's ceremony to block the groom at the door and ask for something as requirement for the groom to enter the bride's house.

\section{j. Hari Bersanding/Hari Langsung ( the reception )}

The day of completion, which also involves the bersanding or ceremonial seating on the bridal dais, is considered the high point of a Malay wedding. In the morning before the bersanding ceremony the bride will change into new clothes, and various fashions may be tried out in selecting the dress to be worn for the bersanding. Then both the bride and the bridegroom are invited for the bersanding ceremony. This is the sitting in state ceremony and theoretically the first time that a bride and her groom meet. Seated on their chairs on the bridal dais.

\section{j. Tepung Tawar}

The meaning of tepung tawar is to offer blessings to both brides and the whole family for happiness, safety, and well-being, enough income, given the sholeh and sholehah children.In addition to tepung tawar is also intended as a symbol of rejection of negative things that may be received in the future. Thus, the ceremony of tepung tawar means as prayer and hope. Tepung tawar is also process of request to Allah SWT through traditional media (tools such as water, flowers).

\section{k. Makan Nasi Hadap-hadapan ( spreading meals )}

Makan Nasi Hadap-hadapan was attended only women from both of bride and groom family, while men were not allowed to participate. Bride and groom are brought to room or in front of pelamin that has been served complete Nasi hadap-hadapan with all traditional food and cakes. After the bride, groom, and the women eat all traditional food and cakes, then the next process is grab the grilled chicken. the rules of this process, when a husband gets a grilled chicken head symbolizes a responsible leader and if his wife gets a chicken thigh symbolizes as a mother who will give children. Makan Nasi Hadap-hadapan contains the meaning of pure love between wife and husband.

\section{Menyembah Mertua (kissing the hands of the parents)}

Menyembah mertua is the event shake hands with parents and family, both of bride and groom or in Javanese custom this event is called by sungkeman which aims to beg the blessing and prayer from all family that exists.

\section{m. Mandi Kumbo Taman (bridal shower)}

Mandi Kumbo Taman is an event that is a joy for the bride and groom's family because the wedding ceremony runs well. Mandi berdimbar is a bridal shower with water, flowers, and some other ingredients. In mandi berdimbar sometimes at first performed the ceremony of hitting mayang leaf, cracking eggs, young coconut, and bersembur-semburan bathing. People also participated in bersembur-semburan bathing. When exposed to spray water from berdimbar bath 
for the youth girls or boys, is believed to quickly get a mate.In communicating the idea, the people involved in all stages are required idiomatic expressions.

\section{Research Methods}

This study was conducted by applying descriptive qualitative research. According to Kothari (2004:2) descriptive research is description of the state of affairs as it exists at present. Descriptive research includes surveys and fact-finding enquiries of different kinds. Kothari (2004:5) also asserts that qualitative approach to research is concerned with subjective assessment of attitude, opinions and behaviour. Some of the data were taken by interviewing the Telangkai, someone who is in charge and responsible in the wedding ceremony. By analyzing and studying Idiomatic Expression MLWC data, results and data are collected. Also, several studies regarding idiomatic expressions, how to improve their acquisition and how to better teach them have been studied, compared and summarized. Results have been reached and stated based on such findings.

\section{Discussion}

The data were analyzed based on the Charles Hockett (1970) Theory to find out the types of idiomatic expression in MLWC, and the realization of Idiomatic Expressions were analyzed Based on Chaer (2012:296) theory who stated that there are two forms of the idiomatic usage, namely Pure and Semi Idioms. In this section the description of the obtained data is firstly presented and the followed by the data analysis and the explanation about the idiomatic expression that found in the Processes. The number and percentage of the types of idiomatic expression in MLWC are shown in the following tables.

Table 1. Realization of Idiomatic Expression in MLWC

\begin{tabular}{|c|c|c|c|c|c|c|c|c|}
\hline \multirow[t]{2}{*}{ No } & \multirow[t]{2}{*}{ Idioms } & \multicolumn{2}{|c|}{ Forms of Idiom } & \multicolumn{5}{|c|}{ Types of Idioms } \\
\hline & & Pure & Semi & FS & $\mathrm{AB}$ & $\mathbf{P N}$ & Sub & EPC \\
\hline 1. & Kehondak Hati & & $\sqrt{ }$ & $\sqrt{ }$ & & & & \\
\hline 2. & Daten Melati & & $\sqrt{ }$ & & & $\sqrt{ }$ & & \\
\hline 3. & Penawar Sojok & $\sqrt{ }$ & & & & $\sqrt{ }$ & & \\
\hline 4. & Kota Betuah & & $\sqrt{ }$ & & & $\sqrt{ }$ & & \\
\hline 5. & Memonuhi Syarat & & $\sqrt{ }$ & $\sqrt{ }$ & & & & \\
\hline 6. & Bukalah Pintu & $\sqrt{ }$ & & $\sqrt{ }$ & & & & \\
\hline 7. & Ikan Menari & & $\sqrt{ }$ & $\sqrt{ }$ & & & & \\
\hline 8. & Memakai Tongkang & & $\sqrt{ }$ & & & $\sqrt{ }$ & & \\
\hline 9. & Mundur Kebelakang & $\sqrt{ }$ & & $\sqrt{ }$ & & & & \\
\hline 10. & Akrabkan Gurau & & $\sqrt{ }$ & $\sqrt{ }$ & & & & \\
\hline 11. & Sodap Bertangkup & & $\sqrt{ }$ & $\sqrt{ }$ & & & & \\
\hline 12. & Tepung Tawar & $\sqrt{ }$ & & $\sqrt{ }$ & & & & \\
\hline 13. & Tepung Sejati & $\sqrt{ }$ & & $\sqrt{ }$ & & & & \\
\hline 14. & Zaman Siti Nurbaya & & $\sqrt{ }$ & & & $\sqrt{ }$ & & \\
\hline 15. & Dua sejoli & & $\sqrt{ }$ & & & $\sqrt{ }$ & & \\
\hline 16. & $\begin{array}{l}\text { Tegakkan Lima } \\
\text { Waktu }\end{array}$ & $\sqrt{ }$ & & $\sqrt{ }$ & & & & \\
\hline 17. & Ketanah Seborang & $\sqrt{ }$ & & & & $\sqrt{ }$ & & \\
\hline 18. & Pinang dibolah Dua & $\sqrt{ }$ & & $\sqrt{ }$ & & & & \\
\hline
\end{tabular}




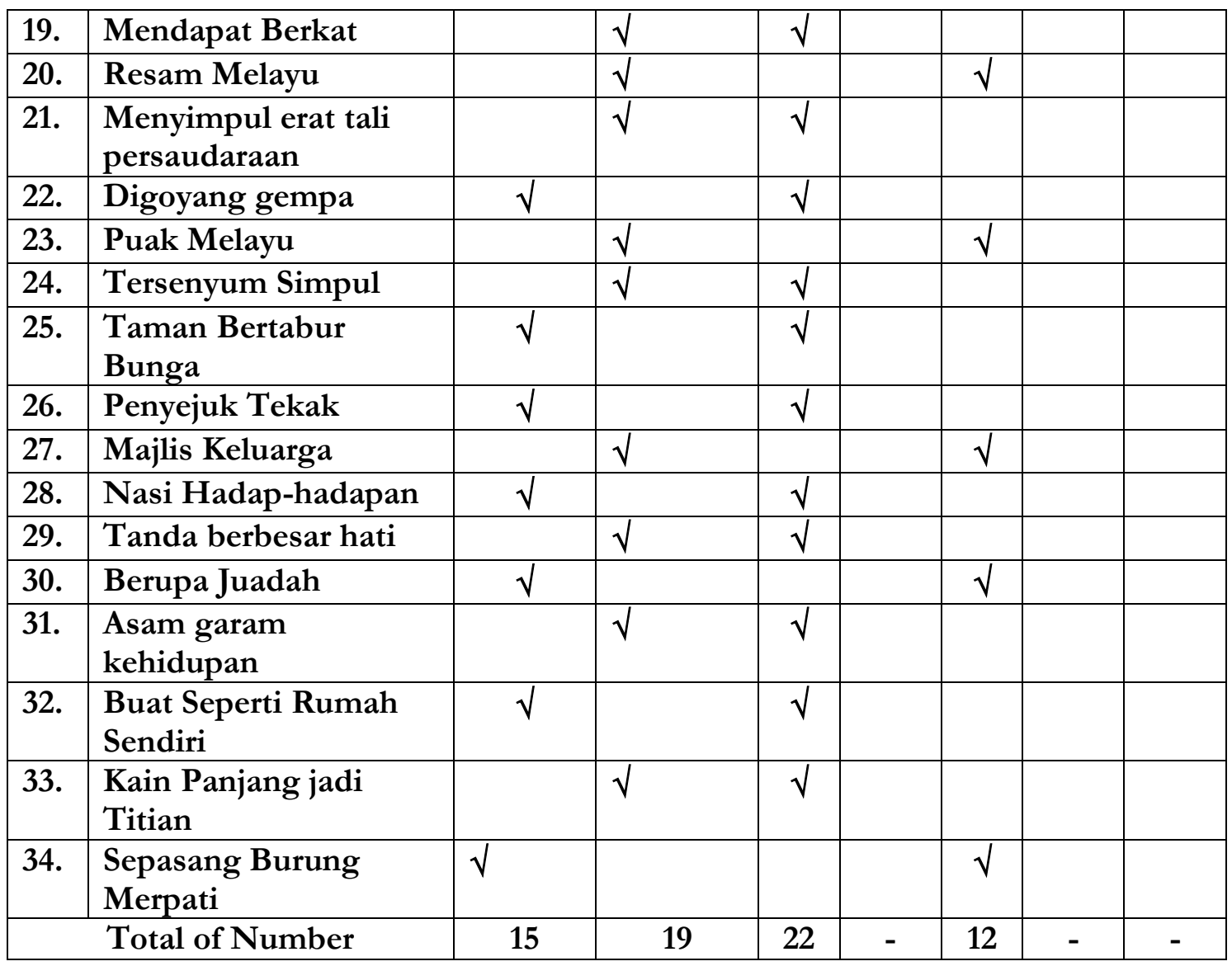

In this table it is shown that the realization of idiomatic expression used in MLWC are 34 idioms.

Table 4.2 The forms of idiomatic Expression in MLWC

\begin{tabular}{|c|c|c|}
\hline Forms of Idioms & Number of Idioms & Percentage \\
\hline Pure Idiom & 15 & $44 \%$ \\
\hline Semi Idiom & 19 & $56 \%$ \\
\hline Total & 34 & $100 \%$ \\
\hline
\end{tabular}

From the table above it is shown that the dominant forms of idiomatic expression in MLWC Semi Idiom. It is 19 number of idioms (56\%). The realization of using idiom in MLWC described through the forms of idiomatic expression. According to Chaer (2012) there are two types of the idiomatic usage. Namely Pure and Semi Idioms. Pure Idioms are idioms which all items have lost its lexical meaning. It means the idiom cannot be literally translated. e.g. Awak ditahan Takkan Dilopas, Sebolum Menyorabkan Penawar Sojok. Penawar Sojok cannot literally be translated as the cold bidder, Penawar if literally translated as a medicine taken or given to counteract a particular poison. And Sojok or cold was literally translated as the low temperature, Idiom of Penawar Sojok in Malay is defined as the requirement that must be submitted by the groomsmen to the Bride's family, and the requirement was Money.

Semi idioms are idioms which have not lost all their lexical items. e.g. Bunda selalu bagai penuntun Sudah melewati Asam Garam Kebidupan. Asam Garam cannot be translated as the acid and 
salt, Asam garam is defined as the life experiences of the human, and in this context the word Kebidupan has the its lexical meaning. Kehidupan is translated as the life or existance of the human.

Table 4.3 The types of Idiomatic Expression In MLWC

Note:

\begin{tabular}{|c|c|c|}
\hline Types of Idioms & Number of Idioms & Percentage \\
\hline FS & 22 & $64,7 \%$ \\
\hline AB & - & - \\
\hline PN & 12 & $35,3 \%$ \\
\hline SUB & - & - \\
\hline EPC & - & - \\
\hline Total & $\mathbf{3 4}$ & $\mathbf{1 0 0} \%$ \\
\hline
\end{tabular}

FS : Figure of Speech

SUB : Substitute

AB : Abbreviation

PN : Proper Names

EPC : English Phrasal Compound

In table 4.3, it is shown that the dominant types of idiomatic expression which found in MLWC is Figure of Speech which amount to $22(64,7 \%)$. In Data analysis below, the Idiomatic Expressions are classified based on the types that found in the Malay Labuhanbatu wedding process.

\begin{tabular}{|l|l|l|}
\hline Types of Idioms & Example & Explanation \\
\hline a. Figure of Speech & $\begin{array}{l}\text { Kalau Boleh Kami Bertanyo } \\
\text { Apa Kehondak Hati Tuan } \\
\text { dan Puan yang datang }\end{array}$ & $\begin{array}{l}\text { Kehondak Hati, Kehondak literally } \\
\text { translated as the Human Desire and } \\
\text { Willingness, and Hati is one of the } \\
\text { human's organ which pump the } \\
\text { human blood, the idiom Kehondak } \\
\text { Hati is defined as the purpose of } \\
\text { groomsmen came to the bride's } \\
\text { house. }\end{array}$ \\
\hline a. Proper Names & $\begin{array}{l}\text { Puteri Raja Daten Melati, } \\
\text { Asyike Bermain Sampai } \\
\text { Kepotang }\end{array}$ & $\begin{array}{l}\text { The idiom of Daten Melati is defined } \\
\text { as The Title given to the beautiful } \\
\text { wife of king in Malay. For Malay } \\
\text { people Melati or Jasmine described as } \\
\text { the symbol of beauty, purity, and } \\
\text { sincerity. }\end{array}$ \\
\hline
\end{tabular}

\section{Conclusion}

Based on the results there are 34 Idiomatic Expression found in MLWC and there were only 2 (Two) types of Idiomatic Expression applied in it namely: Figure of Speech (64,7\%) and Proper Names (35,3\%). Idiomatic Expressions in MLWC are applied in two forms, they are pure idioms (44\%) and semi idioms (56\%). Telangkai used Idiom are to conveyed the Idea and massages politely, Idiom realized in Pantun or Utterances in the MLWC.The dominant form of idiomatic expression found in Malay Labuhanbatu Wedding Ceremony is Semi Idiom (56 \%) and the dominant types is figure of speech $(64,7 \%)$. Based on the result of interview with the two Telangkai, Malay Labuhanbatu wedding ceremony are used to maintain the respect in the social relation of society, to preserve the Idiomatic Expresssion in Malay Labuhanbatu, and to enrich the Malay language, and the last to present the Malay Culture through the use of idiom. 


\section{References}

Alwasilah, A. Chaedar. (1993). Linguistik Suatu Pengantar. Bandung: Angkasa Bandung. Arifin, Zainal. (2009). Adat Budaya Resam Melayu Langkat. Medan : Mitra. .(2012). Linguistik Umum. Jakarta: Rineka Cipta.

Chierchia, Gennaro, Sally McConnell-Ginet. (1992). An Introduction to Semantics. The MIT Press. Cipollone,Nick, Steven Hartman Keiser, Shravan Vasishth. (1998). Language Files, Material for an Introduction to language \& Linguistics. Ohio State University Press.

Emelia, Tengku Winona. (2017). "Tradisi Lisan Cenggok-Cenggok pada Upacara Adat Perkawinan Melayu Panai Labuhanbatu-Sumatera Utara”. (Disertasi). Medan: Fakultas Ilmu Budaya USU.

George, Yule. (2006). The Study of Language. USA: Cambridge University Press.

Gleason, Jean Berko, Nan Bernstein Ratner. (1998). Psycholinguistic. USA: Wadsworth.

Kothari, C.R. (2004). Research Methodology: Methods and Techniques. New Age International Publishers.

Kramsch, Claire. (1998). Language and Culture. Oxford University Press.

Luckman, Tuanku. (2005). Adat Budaya Melayu Jati Diri dan Kepribadian. Sumatera Utara: Forkala.

Takari, Muhammad, A. Zaidan B.S., Fadlin Muhammad Dja'far. (2014). Adat Perkawinan Melayu: Gagasan, Terapan, Fungsi, dan Kearifannya. USU Press. 